\title{
Michael Addition of 2, 4 Thiazolindione on Chalcone Mediated by Lipase in Nonaqueous Solvent
}

\author{
Nitesh D. Punyapreddiwar ${ }^{1}$, Humesh D. Anande, ${ }^{2}$ Ganesh D. Satpute ${ }^{3}$, Suresh B. Rewatkar4 \\ ${ }^{1}$ Department of Chemistry, Shri JSPM College Dhanora Gadchiroli, Maharashtra, India \\ ${ }^{2}$ Department of Chemistry, Gramgeeta College Chimur, Maharashtra, India \\ ${ }^{3}$ Department of Chemistry, Shri G. M. College Kurkheda Gadchiroli, Maharashtra, India \\ ${ }^{4}$ Dea, Faculty of Science \& Technology, Gondwana University, Gadchiroli, Maharashtra, India \\ Email :- nitesh280988@gmail.com
}

\author{
Article Info \\ Volume 8, Issue 1 \\ Page Number: 01-06 \\ Publication Issue : \\ January-February-2021 \\ Article History \\ Accepted : 01 Jan 2021 \\ Published : 04 Jan 2021
}

\section{ABSTRACT}

Biocatalysts are highly enantioselctive catalysts that enforce reactive conformations of nature substrate. We report here a novel type of Michael additions on chalcone catalysed by lipase in nonaqueos solvent in efficient conditions. We first time report 2, 4 thiazolindione as Michael donor for Michael additions on chalcone, isolated product with excellent yield.

Keywords : Chalcone, Thiazolindione, Michael Addition, Organic Solvent

\section{INTRODUCTION}

Biocatalysis is an efficient and green tool for modern organic synthesis due to its high selectivity and mild condition, biocatalytic promiscuity provide new tool for organic synthesis and expand largely application of lipase..$^{1-6}$

Among the catalytically promiscuous lipase, one of the mostly used as hydrolase, because of its good stability and high catalytic activity. Lipase are usually catalyses hydrolysis of ester bond in triglyceride, some lipase-catalysed unconventional reactions such as aldol, ${ }^{7}$ nitroaldol, ${ }^{8}$ mannish condensation, ${ }^{9}$ michael reaction, ${ }^{10}$ markovnikov additions ${ }^{11}$ and acylation's, ${ }^{12}$ have been reported in past decade.

Lipase enzyme used in aqueous medium is not useful for most of the organic reactions because substrates are not soluble in aqueous medium therefore the use of lipase enzyme in organic solvent is gaining much importance. The advantages of lipase enzyme in organic solvent such as (1) most of organic compound are soluble in organic solvent (2) product recover easier than aqoueos media (3) insolubility of bicatalyst in organic solvent which permit their easy recovery and reuse. ${ }^{13-14 .}$

Michael addition on chalcone with different nucleophile is important $\mathrm{C}-\mathrm{C}$ bond forming reaction in organic chemistry. The conjugate addition of carbanion nucleophile to unsaturated carbonyl compound represents one of the best established construction strategies for this purpose. Thus development of asymmetric catalytic version of this type of transformations has been developing intensive over past several years. ${ }^{15-19}$. 
Here employed first time thiazolindione as nucleophile, in thiazolindione methylene hydrogen atom are highly acidic due to presence of two carbonyl. Our important of thiazolindione and chalcone, we develop efficient michael addition involved thiazolindione is still highly desirable.

Generally, michael addition are conducted in a suitable solvent in presence of strong base at room temperatures or at elevated temperatures, due to presence of strong base, side reaction such as multiple condensation, polymerisation, rearrangements. ${ }^{20-23}$. This type of drawback can overcome by biocatalyst, therefore selected biocatalytic protocol for michael addition.

Chalcone and their derivatives demonstrate wide range of biological activities such as anti-diabetic, anti-neoplastic, anti-hypertensive, anti-retroviral, anti-inflammatory, anti-parasital, anti-histaminic, anti-malarial, anti-oxidant, anti-fungal, anti-obesity, anti-platelet, anti-tubercular, immunosuppressant, anti-arrhythmic, hypnotic, anti-gout, anxiolytic, antispasmodic, anti-nociceptive, hypolipidemic, antifilarial, anti-angiogenic, anti-protozoal, anti-bacterial, anti-steroidal. $^{24-27}$

The thiazolidinedione also known as glitazones are a class of medications used in the treatment of diabetics. Then addition of two moieties like chalcone and thiazolindione to give resulting product shows highly biological activity. ${ }^{28-30}$

Catalytic power of lipase and uses of resulting product, Therefore we report develop green develop, Michael addition on chalcone with thiazolindione in acetonitrile solvent under mild condition. Resulting product is novel because, resulting product are not previously reported with any catalyst.

\section{RESULTS AND DISCUSSION}

Herein, first time we report a michael addition on chalcone with 2, 4 thiazolindione under mild condition catalysed Candida antatica lipase-B as biocatalyst.

In order get best experimental condition, we have considered the reaction of chalcone (1a) and 2, 4 thiazolindione (2) in presence of lipase (CAL-B)) as model reaction. (Scheme-1)

In order to best experimental result, lipase used in different organic solvent which included ethanol $\left(\mathrm{C}_{2} \mathrm{H}_{5} \mathrm{OH}\right)$, methanol $\left(\mathrm{CH}_{3} \mathrm{OH}\right)$, acetonitrile $(\mathrm{ACN})$, dimethyl sulphoxide (DMSO), dimethylformamide (DMF), and dichloromethane (DCM). Reaction proceeds in all organic solvent (Table-1 entry 1-6). We analysed the all solvent, acetonitrile is best solvent for this reaction because of reaction required less time and high yield of product (Table-1 entry 3 ) compare to other solvent. Then acetonitrile was selected for model reaction.

Model reaction was proceeding without catalyst in acetonitrile solvent but no conversion even after 32 hrs. Model reaction in presence of different lipase \& their amount analysed the reaction. First taken porcine pancreases lipase $(50 \mathrm{mg})$ and $(100 \mathrm{mg})$ reaction was successfully formation of product in 32 hrs. (Table-2, entry-1-2), then lipase from CAL-B (50 $\mathrm{mg}$ ) and (100mg) reaction was successfully formation of product in $30 \mathrm{hrs}$.(Table-2,entry 3-4) finally lipase from Candida rugosa $(50 \mathrm{mg})$ and $(100 \mathrm{mg})$ reaction continue stirring with 32 hrs but no conversion of product. After analysed better result in lipase from CAL-B in $100 \mathrm{mg}$. Finally model reaction was selected with lipase from CAL-B (100 mg) and acetonitrile solvent. 
To generalise of chalcone, variety of chalcones react with thiazolindione by using lipase (CAL-B) in acetonitrile (Table-2 entry 1-12). we are prepared chalcone by using acetophenone and benzaldehyde in presence of sodium hydroxide in mixture of ethanol and water solvent. Thiazolindione are also prepared by reporting literature using Chloroacetic acid and thiourea in water.

Variety of chalcone containing electron donating and electron withdrawing group attaches to either acetophenone ring or benzaldehyde ring were successfully employed to prepared corresponding product. We conclude that Chloro substitution chalcone to give higher yield or better result. Firstly simple acetophenone containing ring and chloro, nitro substitution on benzaldehyde ring containing chalcone give desire product (Table 2, entry 1-4), then 2-hydroxy substituted acetophenone with chloro,nitro,metoxy,furyl substituted benzaldehyde containing chalcone give desire product (Table 2, entry 5-8), then 4-hydroxy substituted acetophenone ring with methoxy substituted ring benzaldehyde containing chalcone to give desire product ( Table 2 , entry 9-10), finally 3,4 Methoxy acetophenone containing ring with Chloro substituted benzaldehyde ring containing chalcone give desire product(Table 2,entry 11-12)

Lipase is an enzyme, Enzyme contains acidic, basic and neutral amino acid. Michael addition reaction required base but here histidine as base is because of imidazole is basic unit present. Thus histidine accepts highly acidic hydrogen of nitrogen of thiazolindione and formation of nitrine and this nitrine ions attached to $\beta$ carbon of $\alpha, \beta$ unsaturated carbonyl compound, thus formation of $\mathrm{C}-\mathrm{N}$ bond and enolate ions, Finally enolate ion converted into keto form to give product.

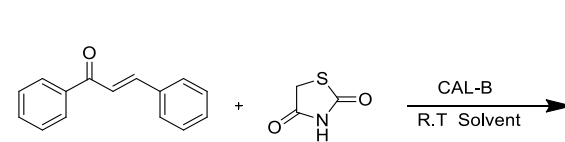

1a

2

\section{Scheme-1}

Table-1 Effect of solvent on Michael addition on chalcone with thiazolindione catalysed by Lipase (CAL-B)

\begin{tabular}{cccc}
\hline Entry & Solvent & Time(hrs) & Yield $^{\mathrm{b}}$ (\%) \\
\hline $\mathbf{1}$ & $\mathrm{C}_{2} \mathrm{H}_{5} \mathrm{OH}$ & 32 & N.R $^{\mathrm{c}}$ \\
$\mathbf{2}$ & $\mathrm{CH}_{3} \mathrm{OH}$ & 32 & N.R $^{\mathrm{c}}$ \\
$\mathbf{3}$ & $\mathrm{DMSO}$ & 32 & 63 \\
$\mathbf{4}$ & $\mathrm{ACN}$ & 32 & 90 \\
$\mathbf{5}$ & $\mathrm{DCM}$ & 32 & 77 \\
$\mathbf{6}$ & $\mathrm{DMF}$ & 32 & 60 \\
\hline
\end{tabular}

aReaction condition-Chalcone ( $5 \mathrm{mmol})$,

thiazolindione (5mmol), Lipase CAL-B (100 mg) and $20 \mathrm{ml}$ solvent at room temp. 'Isolated yield. ${ }^{\mathrm{N} o}$ reaction

Table-2 Effect of catalyst \& amount on Michael addition on chalcone with thiazolindione in acetonitrile solvent

\begin{tabular}{ccccc}
\hline S. & Lipase & Amount(mg) & Time(hrs) & Yield (\%) $^{\mathrm{b}}$ (\% \\
& & & & \\
\hline $\mathbf{1}$ & PPL & 50 & 32 & 45 \\
$\mathbf{2}$ & PPL & 100 & 32 & 55 \\
$\mathbf{3}$ & CAL-B & 50 & 32 & 54 \\
$\mathbf{4}$ & CAL-B & 100 & 32 & 90 \\
$\mathbf{5}$ & C. & 50 & 32 & N.R \\
& rugosa & & & \\
$\mathbf{6}$ & C. & 100 & 32 & N.Rc \\
& rugosa & & & \\
\hline
\end{tabular}

aReaction condition [chalcone $(5 \mathrm{mmol})$, thiazolindione $(5 \mathrm{mmol})$, Acetonitrile $(20 \mathrm{ml})$ and catalyst at room temp. bIsolated yield. ${ }^{\mathrm{N}}$ No reaction 


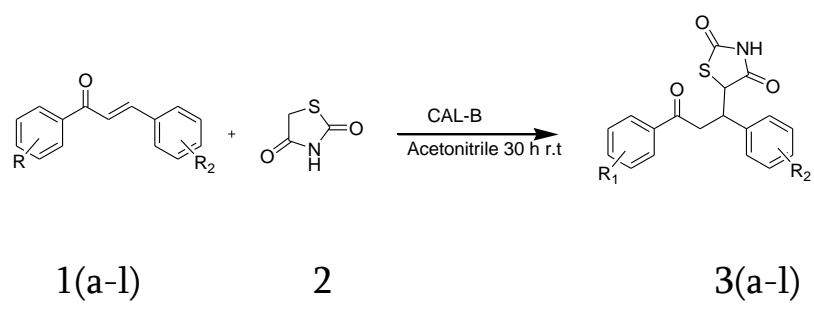

Scheme-2
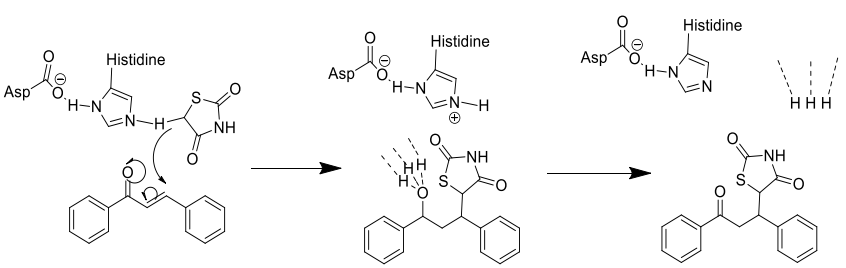

Fig 1; Plausible mechanism of michael addition reaction

Table-3 Lipase catalysed Michael addition on chalcone derivatives with thiazolindione in organic solvent. ${ }^{\mathrm{a}}$

\begin{tabular}{ccccc}
\hline Entry & $\mathbf{R}_{1}$ & $\mathbf{R}_{2}$ & Product $^{\mathbf{c}}$ & Yield $^{\mathbf{b}}$ \\
\hline $\mathbf{1}$ & $\mathrm{H}$ & $\mathrm{H}$ & $3 \mathrm{a}$ & 90 \\
$\mathbf{2}$ & $\mathrm{H}$ & $4-\mathrm{Cl}$ & $3 \mathrm{~b}$ & 85 \\
$\mathbf{3}$ & $\mathrm{H}$ & $3-\mathrm{NO}_{2}$ & $3 \mathrm{c}$ & 82 \\
$\mathbf{4}$ & $\mathrm{H}$ & $2-\mathrm{Cl}$ & $3 \mathrm{~d}$ & 80 \\
$\mathbf{5}$ & $2-\mathrm{OH}$ & $3-\mathrm{NO}_{2}$ & $3 \mathrm{e}$ & 85 \\
$\mathbf{6}$ & $2-\mathrm{OH}$ & $2-\mathrm{Cl}$ & $3 \mathrm{f}$ & 82 \\
$\mathbf{7}$ & $2-\mathrm{OH}$ & $4-\mathrm{OCH}$ & $3 \mathrm{~g}$ & 88 \\
$\mathbf{8}$ & $2-\mathrm{OH}$ & $4-\mathrm{Cl}$ & $3 \mathrm{~h}$ & 78 \\
$\mathbf{9}$ & $4-\mathrm{OH}$ & $\mathrm{H}$ & $3 \mathrm{i}$ & 82 \\
10 & $4-\mathrm{OH}$ & $4-\mathrm{Cl}$ & $3 \mathrm{j}$ & 82 \\
11 & $3,4-\mathrm{OCH}$ & $\mathrm{H}$ & $3 \mathrm{k}$ & 76 \\
12 & $3,4-\mathrm{OCH} \mathrm{H}_{3}$ & $4-\mathrm{Cl}$ & $3 \mathrm{l}$ & 78 \\
\hline
\end{tabular}

aReaction condition-chalcone (5 $\mathrm{mmol})$, thiazolindione (5 mmol), lipase CAL-B (100 mg) and acetonitrile $(20 \mathrm{ml})$ at room temperature stirring for 32 hrs. ${ }^{b}$ Isolated yield c Product characterised by ${ }^{1} \mathrm{HNMR},{ }^{13} \mathrm{C}$ NMR and MS

\section{III.CONCLUSION}

In summary, first time successfully novel efficient michael addition on chalcone with thiazolindione catalysed by lipase. Prominent among the advantages of this new method are novelty, good yield, ecofriendly, and easy workup. Thus further studies on asymmetric reaction catalysed by lipase in our laboratory

\section{IV.EXPERIMENTAL}

General- All Chemicals purchase from commercial supplier \& used without further purification. Lipase purchase from Sigma Aldrich, ${ }^{1} \mathrm{H}$ NMR and ${ }^{13} \mathrm{NMR}$ Spectra were recorded on Bucker Advanced II $400 \mathrm{MHz}$ spectrometer at ambient temperature in DMSO solvent at SAIF. Punjab University Chandigarh. Mass spectra were recorded using JMST100LC, Accu TOF in acetonitrile solvent at SAIF,CDRI Lucknow.Thin Layer chromatography was carried out aluminium backed plates pre-coated with silica gel 60 .were visualised by quenching of UV florescence.

General experimental procedure for Michael addition on chalcone

A mixture of Chalcone (5 mmol), and thiazolindione (5 mmol) was dissolved in acetonitrile $(15 \mathrm{~mL}$ ) containing RB flask $(50 \mathrm{~mL})$, then adding lipase CALB (100 mg).Then reaction was continues stirring at room temperature on magnetic stirrer. The progress of the reaction was monitored by thin layer chromatography, after completion of reaction (30 h), reaction mixture was filtered to remove the catalyst and washed with acetonitrile. The filtrate was in rotary evaporator to obtain crude product. Purification is done by crystallisation from ethanol. 


\section{Spectral data of synthesize compounds}

4.2.1 2-Methylene -3(3-oxo -1,3 diphenyl propyl) thiazolindione (3a): Yellow solid

${ }^{1} \mathrm{H}$ NMR-(400 MHz, DMSO) $\delta$ ppm 12.00 (s, 1H), 7.96 $(\mathrm{t}, 2 \mathrm{H}, J=8.8 \mathrm{~Hz}), 7.58(\mathrm{t}, 1 \mathrm{H}, J=7.6 \mathrm{Mz}), 7.49(\mathrm{t}, 2 \mathrm{H}, J=$ $7.0 \mathrm{~Hz}$ ), 7.35( t, $2 \mathrm{H}, J=8.4 \mathrm{~Hz}$ ), $7.22(\mathrm{~d}, 2 \mathrm{H}, J=7.4 \mathrm{~Hz}$ ), $4.6(\mathrm{t}, 1 \mathrm{H}, J=7.0 \mathrm{~Hz}), 3.4(\mathrm{~s}, 2 \mathrm{H}), 3.2(\mathrm{dd}, 2 \mathrm{H}, J=7.0,7.4$ $\mathrm{Hz})$.

${ }^{13} \mathrm{C}$ NMR (100 MHz, DMSO) $\delta$ ppm 197.06, 173.40, 172.76, 141.17, 136.42, 132.99, 132.94, 129.27, 128.40, $127.45,126.95,78.63,42.82,35.4$

\section{REFERENCES}

[1]. Pratap, U. R., Jawale, D. V., Londhe, B. S. \& Mane, R. A. Baker's yeast catalyzed synthesis of 1,4-benzothiazines, performed under ultrasonication. J. Mol. Catal. B Enzym. 68, 9497 (2011).

[2]. Pyo, S. H. \& Hatti-Kaul, R. Selective, green synthesis of six-membered cyclic carbonates by lipase-catalyzed chemospecific transesterification of diols with dimethyl carbonate. Adv. Synth. Catal. 354, 797-802 (2012).

[3]. Lim, J. Y. et al. Experimental and computation studies on Candida antarctica lipase B-catalyzed enantioselective alcoholysis of 4-bromomethyl$\beta$-lactone leading to enantiopure 4-bromo-3hydroxybutanoate. Adv. Synth. Catal. 355, 18081816 (2013).

[4]. Singh, N. G., Nongrum, R., Kathing, C., Rani, J. W. S. \& Nongkhlaw, R. Bakers' yeast: an environment benign catalyst for the one-pot synthesis of indolyl chromenes and bisindolyl alkanes. Green Chem. Lett. Rev. 7, 137-144 (2014).

[5]. Aouf, C. et al. The use of lipases as biocatalysts for the epoxidation of fatty acids and phenolic compounds. Green Chem. 16, 17406-1754 (2014).
[6]. Haoran, W. et al. Enzyme catalytic promiscuity: asymmetric aldol addition reaction catalyzed by a novel thermophilic esterase in organic solvent. Green Chem. Lett. Rev. 7, 145-149 (2014).

[7]. Milner, S. E., Moody, T. S. \& Maguire, A. R. Biocatalytic approaches to the Henry (nitroaldol) reaction. European J. Org. Chem. 3059-3067 (2012). doi:10.1002/ejoc.201101840

[8]. Asiri, A. M. et al. Green synthesis, characterization, photophysical and electrochemical properties of bis-chalcones. Int. J. Electrochem. Sci. 9, 799-809 (2014).

[9]. Wu, L.-L., Xiang, Y., Yang, D.-C., Guan, Z. \& He, Y.-H. Biocatalytic asymmetric Mannich reaction of ketimines using wheat germ lipase. Catal. Sci. Technol. (2016).

[10].Torre, O., Alfonso, I. \& Gotor, V. Lipase catalysed Michael addition of secondary amines to acrylonitrile. Chem. Commun. (Camb). 435, 1724-1725 (2004).

[11].Wu, W. B., Xu, J. M., Wu, Q., Lv, D. S. \& Lin, X. F. Promiscuous acylases-catalyzed Markovnikov addition of $\mathrm{N}$-heterocycles to vinyl esters in organic media. Adv. Synth. Catal. 348, 487-492 (2006).

[12].Kumar, A. Maurya, R. A. An efficient bakers' yeast catalyzed synthesis of 3,4dihydropyrimidin-2-(1H)-ones. Tetrahedron Lett. 48, 4569-4571 (2007).

[13].Kumar, A. \& Maurya, R. A. Bakers' yeast catalyzed synthesis of polyhydroquinoline derivatives via an unsymmetrical Hantzsch reaction. Tetrahedron Lett. 48, 3887-3890 (2007).

[14].Escalante, J., Carrillo-Morales, M. \& Linzaga, I. Michael additions of amines to methyl acrylates promoted by microwave irradiation. Molecules 13, 340-347 (2008).

[15].Kantam, M. L., Ranganath, K. V. S., Mahendar, K., Chakrapani, L. \& Choudary, B. M. Asymmetric Michael addition of malonates to 
enones catalyzed by nanocrystalline $\mathrm{MgO}$. Tetrahedron Lett. 48, 7646-7649 (2007).

[16].Garg, S. K., Kumar, R. \& Chakraborti, A. K. Copper(II) tetrafluoroborate as a novel and highly efficient catalyst for Michael addition of mercaptans to $\alpha, \beta$-unsaturated carbonyl compounds. Tetrahedron Lett. 46, 1721-1724 (2005).

[17].Rana, N. K., Unhale, R. \& Singh, V. K. Enantioselective sulfa-Michael addition of thioacids to unsaturated ketones with bifunctional organocatalyst. Tetrahedron Lett. 53, 2121-2124 (2012).

[18].Kabashima, H., Tsuji, H., Shibuya, T. \& Hattori, $\mathrm{H}$. Michael addition of nitromethane to $\mathrm{a}, \mathrm{b}-$ unsaturated carbonyl compounds over solid base catalysts. 23-29 (2000).

[19].Yang, W., Jia, Y. \& Du, D.-M. Squaramidecatalyzed enantioselective Michael addition of malononitrile to chalcones. Org. Biomol. Chem. 10, 332 (2012).

[20].Choudary, B. M., Lakshmi Kantam, M., Venkat Reddy, C. R., Koteswara Rao, K. \& Figueras, F. The first example of Michael addition catalysed by modified $\mathrm{Mg}-\mathrm{Al}$ hydrotalcite. J. Mol. Catal. A Chem. 146, 279-284 (1999).

[21].Al-Jaber, N. A., Bougasim, A. S. A. \& Karah, M. M. S. Study of Michael addition on chalcones and or chalcone analogues. J. Saudi Chem. Soc. 16, 45-53 (2012).

[22].Li, X. et al. The asymmetric addition of malononitrile to $\alpha, \beta$-unsaturated ketones catalyzed by $\mathrm{RuCl} 2[(\mathrm{R}, \mathrm{R})-\mathrm{DPEN}](\mathrm{PPh} 3) 2$ as the precatalyst. Tetrahedron Lett. 55, 3868-3872 (2014).

[23].Zhang, S., Wang, L., Feng, X. \& Bao, M. Palladium-catalyzed carbonylative addition of aryl bromides to arylalkynes: a simple and efficient method for chalcone synthesis. Org. Biomol. Chem. 12, 7233-7 (2014).
[24].Wu, S.., Ma, X., Ran, J., Zhang, Y., Qin, F., Liu, Y., Application of Basic Isoreticular Nanoporous Metal-organic Framework: IRMOF-3 as a Suitable and Efficient Catalyst for the Synthesis of Chalcone. RSC Adv. 5, 14221-14227 (2015).

[25].Imran, M., Ilyas, B., Deepanjali \& Khan, S. A. Recent thiazolidinediones as antidiabetics. J. Sci. Ind. Res. (India). 66, 99-109 (2007).

[26].Zhao, D. et al. Synthesis of novel 4-thiazolidione derivatives as antibacterial agents against drugresistant Staphylococcus epidermidis. Med. Chem. Res. 22, 3743-3750 (2013).

[27].Pan, B. et al. Thiazolidione derivatives as novel antibiofilm agents: Design, synthesis, biological evaluation, and structure-activity relationships. Eur. J. Med. Chem. 46, 819-824 (2011).

\section{Cite this article as :}

Nitesh D. Punyapreddiwar, Humesh D. Anande, Ganesh D. Satpute, Suresh B. Rewatkar, "Michael Addition of 2, 4 Thiazolindione on Chalcone Mediated by Lipase in Nonaqueous Solvent ", International Journal of Scientific Research in Science and Technology (IJSRST), Online ISSN : 2395-602X, Print ISSN : 2395-6011, Volume 8 Issue 1, pp. 01-06, January-February 2021. Available at doi : https://doi.org/10.32628/IJSRST207670

Journal URL : http://ijsrst.com/IJSRST207670 